\title{
The Development of Sports Fan: From Self-Identification to "Diehard"
}

\begin{abstract}
By Joe Harasta*
The following insight literature review describes the process that sports fans undergo in the development of their fandom - from the individual, selfidentification phase to the mass-audience, communal experience and ultimately to the "diehard fan" distinction. Sports fans begin their fandom as individual entities who find emotional satisfaction in cheering for a particular team or athlete because those teams and athletes provide an important psychological component or addition to their lives. As fans' connections to teams and athletes grow stronger, they seek out other like-minded individuals to share their emotions and feelings, which helps reinforce these attachments Thus, the communal experience in sports is born. The communal sports fan experience can also set groups against each other for the same reasons - the "us against them" mentality. The spread of new and social media platforms provides even stronger and instantaneous relationship building and maintenance opportunities among sports fans - enabling a "virtual" communal experience. The end result of fervent sports fans' development is to become the most committed fan - the "diehard fan".
\end{abstract}

Keywords: fans, sports, group identity, self-identity, group values, diehard fan, communal experience

\section{Introduction}

The development of sports fans from individuals watching a game or event to the shared communal experience of thousands or even millions of people feeling the same emotions begins with a single person's desire to experience more in life. Developing one's self identity as a fan of a specific team or athlete begins with a craving to experience the same highs and lows as that team or athlete, feel a sense of achievement, and fulfill the desire for a communal experience of shared emotions. The ultimate goal of highly developed and fervent fans is the distinction of becoming "diehard" fans who are respected for their knowledge, loyalty, and longevity. For many, this psychological experience becomes so intense that they seek out others to share their extreme passions, which further reinforces their intense bonds with teams, athletes, and even each other. The following insight literature review outlines the evolution of the sports fan from the solitary individual who develops his or her self-identity as a fan of a team or athlete to the collective connection experienced by masses of fans who want to feel the share emotions felt by one another, and finally to becoming a member of the "diehard fan" family of fans. Essentially, why do certain individuals evolve from people

*Associate Professor, Department of Communication Studies, Kutztown University of Pennsylvania, USA. 
who simply develop an interest in a team to those who devote much of their time, income, passion, and even identity to a sports team? What makes someone a "diehard" fan?

Of course, not all fans seek to become "diehard fans". Others, sometimes to referred to lesser or "fair-weather" fans, will seek connections with fellow fans, but not to the level of "diehard" fans. These lesser fans might be adamant about their fandom during important times, such as when their teams are in championship games; however, "diehard" fans will maintain their high levels of fandom even when their teams are not at the height of success. Simply put, a "diehard" fan can be defined as someone who supports their team regardless of how it performs (Branscombe et al. 1993).

Many researchers agree that the primary psychological influence on being a sports fan is the sense of belonging and the inclusion or membership into a group. University of Wisconsin sociology professors Snow and Oliver (1995) found that the effect of being a fan is a sense of belonging and camaraderie with those like themselves. It helps to define "us" and "them". Sociologist Zillman (1989) adds, "It appears that sports fanship can unite and provide feelings of belongingness that are beneficial to individuals and the social setting in which they live" (p. 241). In contrast, non-fans found little interest in supporting or even caring about a team's performance even when the non-fans lived in the same area where sports fandom is rampant (Van Driel et al. 2019). One can then see the powerful effect that sports fandom has on individuals who elect to support a team or athlete compared to those who do not.

In addition to feelings of belonging, being a sports fan provides the opportunity to participate in activities the fan may not otherwise be able. Wann and Branscombe (1991) found that sports fanaticism allows people to be part of a sporting event who would otherwise have no connection to it. For example, those fans that are unable, or unwilling, to physically participate in sports can vicariously engage in the activities of the athletes they cheer for and support. Also, events such as autograph signings, meet-and-greet, charitable functions provide additional means for fans to connect with their favorite teams and athletes. These events also reinforce bonds with fellow fans. Moreover, fan attachment to their fellow fans can dictate long-term attendance frequency. That is, the more attached fans are to one another, the more likely they are to attend team events and games (Yoshida et al. 2015). The progression from the solitary fan, to group mentality, to "diehard fan" distinction begins with one fan's choice to establish his or her self-identity as a fully committed fan of a team or player. The progression of sports fans from individuals supporting a team or player to the communal experience of thousands or even millions sharing the fan experience is multifaceted. This insight literature review investigates these facets, including the psychological processes, sociological implications, and ultimately to the outward displays of communicative expressions fans use to show their levels of fandom. The communication aspects of this article must therefore be prefaced with the motivations and intentions of fans' communication actions. These communication actions have their motivations in psychological and sociological origins. Katz et al. (2018) add, “...understanding sport fan behaviour necessitates including both psychological and structural 
elements of behaviour" (p. 176). Therefore, it would be impossible to focus purely on the communication aspects of sports fandom without also considering the reasonings and origins of sports fans' communication. The goal of this review is twofold: To add to and encourage greater scholarly understanding of sports fandom so that it might "...advance knowledge of sport consumer behavior in the future" (Lock and Heere 2017, p. 430). Secondly, in addition to increasing the academic understanding of sports fandom and fan development, this review might also benefit teams' management, marketers, and even athletes because it helps understand and explain the fan development process. With this understanding, these entities can then develop and manage actions that can better achieve their public and fan relations objectives and initiatives.

The paper outlines the formation process of sports fans by introducing the purpose of this study; the methods used to acquire resources for analysis; the impact of social identity and role models in sports; Basking In Reflected Glory (BIRG) and Cut off Reflected Failure (CORF) tendencies; social media's impact; nationalism; and the progression from the self to the group-identity of fandom. Highlights from the paper include:

- Insight Literature Review of 126 studies.

- Sports fans connect to certain teams, players, and the geographic areas in which they compete. These teams, players, and areas become part of sports fans' self-identities.

- The communal nature of sports explains why fans congregate together in sports bars or other venues to be with fellow fans.

- Sports fans seek ways to publicly express their feelings toward certain teams, cities, and players through clothing and merchandise, as well as the use of symbols and terminology specific to a team or city.

- The spread of social media enables sports fans to directly communicate with fellow fans, thus enhancing fans' experiences and levels of interaction, which also serves to reinforce self-identification.

- Fans of particular teams or players often make personal and strongly emotional connections to them; the outcome of a game or a player's behavior has a direct impact on their psyche.

- Sports fandom can be thought of as an evolution of changing personality traits and actions beginning with less-involved fans to communal fans and finally to "diehard" fans.

- Not all sports fans move to the level of "diehard" fans; that evolution depends on variables relating to their levels of involvement and personalities. 


\section{Methods}

\section{Search Strategy}

The literature search for this article began in December 2017 and continued until February 2021. Because of the nature of an insight literature review, only publications pertaining to the development of sports fans in the early selfidentification phase, to those on the communal sports experiences, and finally to the highly established fan were included. Article filtration was based on the reasons and effects of sports fans' evolutionary process in becoming a "diehard" fan. As the search continued, additional key elements of sports fandom were further investigated as they arose from the literature. For instance, analyses of social identity theory led to exploring self-categorization theory's effects on fans' evolutionary processes. Sources for this article were obtained through four databases: JSTOR, ProQuest, Communication Source, and Academic Search Ultimate. Only peer-reviewed articles and books were used. Publications not directly relating to sports fandom were excluded because they did not offer insights specific to the sports genre. Articles on popular music fans, for example, would not offer information pertinent to this literature review. Dates of publication ranged from 1968 to 2020 . Studies prior to 1968 were not included so that this insight literature review can concentrate on modern sports fandom with its relationship with new and social media, changing trends, social movements, etc. Titles were gleaned to identify their relevance to this review. From these titles, the abstracts were analyzed to further refine the search of journal articles to be used. This review does not focus purely on gender, ethnicity, or race as influencers on sports fandom. Instead, it should be interpreted as a starting point for future scholars interested in the phenomenon of sports fan development in general. Because it is an insight literature review, it should be viewed as a resource, one among many, that scholars might tap into, not as an all-encompassing summary of all possible influences and effects on sports fandom. The aim of this study is to provide insights into the overall evolutionary development of sports fans today, and to act as a tool for primary scholarly studies. Funk and James' (2001) analysis of fan development and their Psychological Continuum Model (PCM) do provide insights into individual fan development. This review, on the other hand, looks at both the individual, as well as communal sports fandom phenomenon, and its development from the individual to the group perspective from different scholarly perspectives and sources spanning several decades. Also, this review analyzes the influences and effects of mediated communication technology and societal changes and shifts affecting sports fandom, which were either nonexistent or less pronounced in years past. It organizes what is currently known about sports fandom development in the modern world, critically analyzes this knowledge, and discuss the implications of this knowledge. 


\section{Selection Criteria}

Because of the breadth and vastly differing areas of scholarship regarding sports fan study, initial searches included simply "sports fan". Searches were then narrowed to include "sports fan" and "identification"; "sports fan" and "development"; "sports fan" and "motivation"; "sports fan" and "relationships"; and "sports fan" and "communal"; "sport socialization"; "fan socialization"; "fan community"; athlete brand". The full search process and results are available in Appendix A.

\section{Included and Excluded Studies}

Initial searches of the four databases resulted in 431,357 total articles with 209,250 peer-reviewed articles. Due to this volume, articles that duplicated previous studies were excluded if they did not offer additional, new insights into the study of sports fandom. The article review process lasted 38 months for this insight literature review. Because of the unique nature of insight literature reviews, the author identified articles from the searches that were most germane to this review by recognizing those that focused on fan identification and development; fan relationships; fan identification; and fan motivations; as well as communal fan experiences. This search led to the selection of the 126 included pieces of scholarship in this insight literature review. The decision to include articles were based on the following objectives: (a) to identify relevant perspectives relating to the impact of sports fandom on the individual, (b) to describe the studies' impact and importance to the study of fan development, (c) to consider the studies' results impacting various perspectives relating to the study of sports fandom, and (d) recognize the processes and effects of communal sports experiences. Additionally, it is important to understand that this review focuses its attention on selecting articles, and sections of those articles, based on their insights and explanations that could be gleaned to understand the developments of sports fandom today, even though an article in question might be decades old. Because this is not a largescale state-of-the-literature review, but rather a focused insight literature review, the author selected articles that best related to the specific focus of how one evolves and acts as an individual progressing through levels of fandom, which again, is at the heart of this review. Appendix B further illustrates the inclusion and exclusion criteria for the sources used.

\section{Social Identity Theory, Identity Theory, and Sports Fans}

Social psychologist Tajfel (1970) identified social identity theory as the reason why people behave and think as they do. Unlike identity theory, which explains role and role behaviors, social identity theory seeks to explain the behaviors associated with group processes and relations within the group - the communal experience. Both theories share similarities. However, social identity theory is rooted in psychology whereas identity theory stems from a sociological 
perspective. Both theories are important in understanding fan development. Where social identity theory can explain people's roles in groups, identity theory explains the actions they take in those roles (Hogg et al. 1995). For sports fans, identity theory describes individual's role behaviors, while social identity theory can explain levels of fandom within fan groups, as well as those groups' behaviors. In other words, are they non-fans, casual fans, or "diehard" fans, and what does that mean in terms of how they act? The answers to these questions can explain how levels of fans differentiate themselves from each other, as well as why some fans behave as they do while other might behave differently. When combined, these two theories provide greater explanations into the phenomenon of sports fans' roles and actions (Lock and Heere 2017).

Tajfel and Turner (1986) introduced the notion of social identity theory as one in which people possess two identities - their personal identity and their social identity. Social identity theory involves three steps: (1) categorization, (2) identification, and (3) comparison. Built upon Leon Festingers' identity theories, Tajfel asserts that during categorization, people attach themselves to other individuals and groups that are either similar to them or more successful. This helps explain the initial, individual desire to root for a particular team or athlete. Specifically, it is the desire for improved self-image and self-identification that fans attach themselves and their personalities to successful teams and athletes (Wang et al. 2020). After all, why cheer for an unsuccessful team or a poor athlete? However, there are other reasons. Initially, gratification plays a major role in the development of sports fandom. The earliest stage of sports fandom begins with the search for self-gratification through categorization. But the gratification can arise from an individual's desire to "fit in" as well the desire to vicariously attach oneself to a successful sports franchise. To this end, fan development often begins at an early age when children seek attention and more importantly, approval from other - most notably, their parents who might already be fans of a specific team. Multiple In-Group Identity Framework (MIIF) consisting of: (a) subordinate (identification with a team), (b) subgroup (geographical location), and (c) relational group (family, friends, etc.) also helps explain fan development (Lock and Funk 2016). These three areas also help to ascribe levels of fandom, i.e., non or lesser-fans, as well as "diehard", in fan groups based on the degree to which the three frameworks play a role in self-identifying oneself as a sports fan.

In addition to a desire to self-categorize as successful, it can be such parental influences that affect young fans' likelihood of cheering for one team over another (Spaaij and Anderson 2010). In many ways, fanhood can be passed down through family generations, or relational groups (James 2001). The notion is, your grandfather cheered for the Green Bay Packers, so did your father, and so now must you; and someday, your children will as well. This mentality can be so ingrained in young fans that it is difficult to break the chain of family-influenced sports fandom (Kolbe and James 2000). Self-identified fandom is also longlasting. As sports fans age, they adapt to physical and mental changes to maintain a continuity in their relationships with their favorite teams (Smith 2019). In addition to parental influences, other motivations exist that can help explain the 
relationship between sports and fans. Participation in sports also plays a role in fan development, as well as the type of sport.

While Americans closely align themselves to team sports, other nations focus more on individual sports, which can help explain nations' differing fandoms. Melnick and Wann (2004) found that Norwegians see sport as a mostly participatory action more than one where people simply root for others participating in sport. Whereas Americans strongly identify themselves as sports team-focused fans, cultural and social differences in other countries can account for less focus on team fandom found in other nations. Also, access and media focus play a role. In America, fans can choose from over 100 major sports teams. That coupled, with intense marketing and media attention, explains why team fandom is so rampant in the United States (Melnick and Wann 2011). However, other nations' fans share similarities to American fans despite decreased focus on team sports commercialization.

Melnick and Wann's (2011) study of Australian university students found that friends most influenced sports fandom followed by parents, school, and then community. An American study of the same kind duplicated these findings (Wann et al. 2001). A similar study of Greek students found the influence order ranked as friends, parents, community, and school (Theodorakis and Wann 2008. Parry et al (2014) found that young United Kingdom sports fans were most influenced by fathers watching games with sons, and that UK fandom most closely matched fan behavior of American fans rather than other European fans. The socializing agents of friends, family, and community, therefore, can greatly impact sports fandom, especially for young fans. Children seek to establish fan membership among other fans, mostly their friends who are fans, before establishing attachments to specific teams and players (Reifurth et al. 2018). Therefore, young fans seem to place greater importance on "fitting in" with their peers than connecting with a team, which helps illustrate the importance of social identity theory on children's fan development.

\section{Categorization}

Sociologist Jenkins (2008) later found that social identification theory, " ...refers to the way in which individuals and collectives are distinguished in their social relations with other individuals or collectives" (p. 18). Vanderbilt University professor Thoits and Virshup (1997) adds that social identity theory also explains how others accept individuals. That is, the things fans do to gain acceptance and admiration from fellow fans, such as painting their face in the team's colors to outwardly illustrate their loyalty to their fellow fans, act as visible displays of social identification. Young Green Bay Packers fan might not understand why they are wearing foam wedges of cheese on their heads, but they understand the importance that others place on it because they see it in people they admire or respect, like parents. This illustrates the power and significance of these outward signs of fandom. Texas Tech University marketing professor Levarie (2000) adds that social identity is vital to the study of fan psychology because of its societal pervasiveness. Levarie (2000) writes: 
Social identity is applicable because fan behavior is socially visible, involves relationships with others, can lead to the formation of a fan role and one can experience satisfaction with that role. Those people with high identity salience are more likely to participate in identity related activities...those with high identity salience for being a fan of a sporting team will attend games more often than those low in identity salience (p. 230).

Identity salience helps explain the importance that sports fans place on social depictions of themselves as fans of a specific team. Beginning with self-identifying as a fan of a team, fans then move on to showing others around them that they are in fact a fan by wearing clothing or attending events specific to a particular team. These actions act support their growing fandom.

\section{Identification}

Burke (1991) defines the second step of social identity theory, identification, as, "...a set of meanings applied to the self in a social situation defining what it means to be who one is" (p. 836). Sociologists Borgatta (1992) add that the person we choose to be is determined by how much satisfaction we derive from, and how committed we are, to be that person. For sports fans, the level of satisfaction derived from being a fan determines how committed they are to their roles as fans, and consequently their commitment to their favorite team, which is explained by identity theory. The adamant Green Bay Packers fan, for example, might devote hours each week pouring over team news, eagerly seeking to find the latest information on the team twelve months out of the year, whereas a less evolved fan might simply watch each game without much thought of it afterwards. Madrigal (1995) says that this type of identification, as well as the unique experiences associated with watching sporting events, contribute to satisfaction. Levarie (2000) adds, "Attachment to a team could be an important part of one's self. The more attachment a person feels to a team, the more important that identity becomes to their sense of self' (p. 229). Ardent Green Bay Packers fans are not just fans representing that team, that team's identity becomes a part of those fans' identity as well. University of New Orleans professor Dimanche (1994) findings suggest that fans use a sports team for self-concept maintenance, which could account for why some fans become "diehards", while others remain relatively unaffected because of their lesser attachment to a team. That is, ordinary fans become "diehard" fans because they depend so wholly on the role as team booster for selfidentity purposes, and therefore relish deeply in possessing "diehard" status. Burke (1991) agrees saying, "The core of an identity is the categorization of the self as an occupant of a role" (p. 840). In the case of sports fans, it is the category or level of fandom - "fair-weather" or "diehard" - that can lie at the core of their identities. Individuals develop their self-appointed degree of fandom; whether to remain a casual fan or one whose identity is inextricably linked to a team or athlete, during the identification phase. 


\section{Comparison}

The third step in social identity theory, comparison, deals with individuals' desire to gain acceptance and favor by those they attached themselves. For sports fans, that includes fellow fans. Social psychologist Hogg et al. (1995) says identity is formed as a result from membership within a desired group. Tajfel (1970) adds that individuals strive to maintain these social identities by favorably comparing themselves to group members and non-group members. This may explain why Green Bay Packers fans refer to themselves as "Cheeseheads", or that Cleveland Browns fans call their stadium the "Dog Pound". This allows them to distinguish themselves from other football fans and reinforce their common identity. Researchers McCall and Simmons (1996) found that human interactions, like those experienced by football fans in Green Bay or Cleveland, are inextricably linked to the fans' definition of themselves and their world. Tajfel adds that these interactions provide, "...a system of orientation which helps to create and define the individual's place in society" (p. 96).

Sports fans develop and maintain their identities by reinforcing their commonalities and by distancing themselves from rival fans by acts such as wearing team merchandise, i.e., foam cheese hats in Green Bay. They separate themselves from other fans as well through their activities, i.e., hanging effigies of star players of rival teams as Philadelphia Flyers opponents' fans did in the 1970s. Sociologist Callero (1985) says that as fans become more satisfied with their identity, they are more likely to take part in these types of activities that reinforce this identity, which might include viewing and attending more games, buying more team merchandise, etc.

Researchers agree that this identity can be so powerful that it also affects fans' ability to accurately judge the actions of their fellow fans, even when that behavior includes illegal activity. This might account for why riotous behavior is so common in teams' cities following a championship win. In a study on fan behavior at Murray State University, psychologists Wann and Dolan (1994a) used pen and paper surveys to measure the correlation between fan identity and fan perception of the university's basketball team. They found that highly identified fans reported more favorably about fans of their team than rival fan groups, even though both fan groups performed identical behavior. In other words, ardent sports fans might see destroying private property as not as serious an act if it is done by someone who shares in their favorite team's level of fandom. Psychologist Brewer (1979) identified this phenomenon in her studies finding that in-group favoritism is more prevalent and influential than out-group derogation. The commonalities that fellow sports fans share seem to essentially blind them to both their actions, as well as to the actions of their fellow fans. Here, one can see the power of self-identity in shaping the actions and perceptions of sports fans and its impact on their psyche. Moreover, Wann and Dolan (1994a) found that sports fans with a higher identification with a team were more likely to overestimate the performance of that team during past seasons as well as overestimate the team's ability in future seasons. Essentially, as people more fully identify with a team, the more skewed their perceptions of the team become. Wann (1994) later found this phenomenon 
true for teams with both winning and losing records. Essentially, sports fan can wear "rose-colored glasses" when viewing the performance of their team, as well as the actions of their fellow fans. This helps illustrate the power of fandom on fans' mental processes and their ability to rationalize and think realistically about what is true and what is not.

Psychologist and researcher Stryker (1968) found that identity theory also describes why people behave in certain ways - as peculiar as it might be; in this case, sports fans' unique behaviors compared to non-sports fans; such wearing clothing that would be regarded as absurd outside the context of sports fandom. Researcher Petkus (1996) defined this level of identity theory in two parts: the role (in this case the sports fan) and the identity associated with that role (in this case as team supporter). Rational human beings would not wear foam pieces of cheese on their heads in normal, day-to-day life. But, in the role and environment of the team booster, it is not only completely acceptable, but encouraged. Sociologist and University of California professor Burke (1991) explained that this type of behavior occurs because people want to act in a way that causes others to think highly of them. Burke agrees, asserting that someone the individual seeks admiration from will affect how fans behave. That is, fans' identity and subsequent actions will reflect the attitudes of those around them, namely other fans from whom they seek admiration. Fully identified fans might spend thousands of dollars customizing their vehicles in team colors to stand out and separate themselves from whom they see as lesser fans. Also, highly identified fans are also prone to arrange their lives around sports events, prioritize their thoughts and conversations around sports, and invest great time and money on sports (Kenyon and McPherson 1974).

One can perceive this behavior as a result of a type of peer pressure that exists among sports fans, which ultimately influences their behaviors derived from social identity theory. Technology and changes in social issues also play a role in affecting how and why sports fans interact with one another, and how they go about reinforcing their self-identities. Sports fans' "peer pressures" tend to vary based on the sport, level of fandom, and the available technology at the time. Social Identity Theory would then explain why social media usage among fans is so prevalent. It is because of its ability to immediately reinforce intergroup relationships, and it easily enables users to communicate within the fan group more quickly and more directly than ever before. The pervasiveness of social media communication sees its roots based in the communication styles and practices of years past. Uses-and-gratifications theory suggests that sports fans use media, selection of particular outlets, and the content of those selections to meet their needs both socially and psychologically (Rubin 2009). That is, it provides an outlet where fans can virtually meet and discuss major and minor events and news concerning their teams and players, as well as participate in rumor and gossip about them. The psychological ramifications of these virtual conversations arise from users' mental reinforcements of their bonds with fellow fans, teams, and athletes. Ruihley and Pate's (2017) study of sports and brands found that sports fandom centers on the team and athlete they cheer for; their identity with a team or place; and the inspiration they feel from watching and communicating about their 
favorite teams and players. With today's communication technology, the inspiration derived from cheering and identifying with teams and players allows for immediate social and psychological gratification. Green Bay Packers fans in 1950 were no less adamant in their allegiance to the team than fans in 2020 . However, today's fans have the technological means to communicate instantly with millions of other like-minded fans. While technology and public opinion changed over the decades, the motivations of sports fans continue and adapt as new communication opportunities and tools emerge. The self-identity development of sports fans remains unchanged. However, ever-changing technological opportunities can influence today's sports fans, their behaviors, and their means to establish and grow their identity as fans more quickly than in years past. Combined with communication technology, self-identity remains one of the backbones of sports fan development because outside influences still play a major role in affecting fans' self-identities.

For instance, today's celebrity-obsessed culture impacts people's perceptions and shapes their opinions greatly. Consider, for example, the importance that millions of people place on a celebrity or politician's Tweet and how much it influences their opinions and actions. Accordingly, sports fans establish deep trust and beliefs in the athletes they root for, and consequently, athletes become celebrities and influencers who affect sports fans in profound ways. This influence affects sports fans' self-identities because fans, in a sense, take on the identity of the athlete for whom they cheer. This helps explain why breakfast cereals place celebrities on their boxes - a photo of Michel Jordan on a box of Wheaties lets everyone "Be Like Mike", even if it is only at breakfast. The same can be said for the athletes who fans respect most and vice-versa. In Green Bay, a blue-collar, working-class city, fans of its football team value work ethic and commitment. Players who show themselves with this type of reputation consequently become folk heroes in that city. However, athletes can take on great importance to fans for reasons other than their on-field performances, such as their roles in shaping public opinion on societal issues and their overall "marketability" in a commercial sense.

\section{The Athlete as Influencer}

Today's star athletes can be brands in and of themselves. They hold considerable influence over fan consumers. Celebrity athletes affect fans' perceptions and actions based on athletes' on-field performance, physical appearance, and off-the-field marketability stemming from their celebrity (Arai, et al. 2013). Vorderer (2000) suggests that Entertainment Theory can help explain the aspirational nature of celebrity and why it is so impactful in influencing people's thoughts and behaviors - essentially, why people want to mimic or reflect the lifestyles of celebrities. This accounts for the reason why celebrity endorsements are so effective in marketing campaigns. In addition to the level of celebrity, researchers find that a celebrity's industry or profession plays an integral role in the effectiveness of their endorsements (Erdogan 1999). For sports fans, it is the sport, be it football, basketball, etc., that impacts fans' relationships with 
their favorite athletes. Hockey fans, for instance, connect with physically imposing athletes while gymnastics fans might be more attracted to graceful athletes. Additionally, the seasonal nature of sports means that fans' connections to their athlete celebrities can possibly wax and wane. That is, a fan of a baseball player has much more invested in their favorite athlete from April to September. This excitement might be less intense during the off-season, only to reemerge in the spring, just as with a child's excitement grows as Christmas gets nearer and nearer. In a sense, athletes take on a seasonal magnetism - not too different than Santa Claus. However, it is peoples' level of identification with celebrities that plays the greatest role on the how much impact celebrities possess (Basil 2012). Accordingly, the role of professional athletes is critical to self-identified fans' behaviors because of the impact that sports figures have on fans' lives. Highly identified fans will happily pay hundreds or thousands of dollars to mimic their favorite athlete - the popularity, and cost of some sports celebrities' jerseys illustrates this point. Also, membership in the fan community affects fans' consumer tendencies. Greater associations and stronger roles in those communities can equate to increased sports product consumption and team event attendance (Hedlund 2014). This enables fans to demonstrate their commitments, even if superficially, to one another in the fan group. Consumer culture and material culture also play a role in the outward expressions of sport solidarity with a team or player. Crawford (2004) found:

Sport-related consumer items can signify membership to a local or more distant community, dedication to a club, sport, or team, [and] 'authenticity' as a 'real' fan... the meanings 'read' from these can also frequently differ from those that were intended by the wearer, for as argued, clothing and similar consumer items operate as poor forms or communication (pp. 57-58).

Giulianotti and Robertson (2004) furthered the notion of fans' consumeristic tendencies, or personalities, by categorizing them into four fan types in his study of British football clubs. These include Supporter, Fan, Follower, and Flaneur. The most ardent, or hot categories, are those of the Supporter and Fan who maintain strong loyalties with teams whereas Followers and Flaneurs' solidarities with teams is weaker or superficial and more motivated by the need to play the part of a fan rather than being a loyal supporter. The thin forms of solidarity with teams and athletes often play to the consumeristic nature of modern displays of sports team allegiance, or the lack thereof. In essence, "diehard" fans best exemplify the thick and hot categorizations of Giulianotti's sports fandom taxonomies. Crawford (2004) provides a fine example:

For instance, the 'NY' logo of the New York Yankees baseball team is one of the most common symbols to appear on baseball caps in the UK, but it is unlikely that many of the wearers of these will likely have an allegiance with the Yankees, and many might not even associate with the team (p. 57).

Thus, these types of fashion-focused, rather than fan-focused, displays of sports team "allegiance" evident today center on superficial appearances instead of 
commitment. This phenomenon also plays into today's celebrity-obsessed culture. To that end, Roy and Mishra (2018) found that the status of celebrities impacts their influence on fans. The more important, and famous/accomplished an athlete, the more influential they are. Fans judge the aspirational status of athletes according to their expertise and sportsmanship, the symbol of who and what they represent, and their life story or role model appropriateness (Arai et al. 2014). Therefore, the fervent nature of sports fandom plays perfectly into the role of the celebrity endorser. The mentality is essentially, if I eat the same breakfast cereal as the athletes I root for, then my connection to those athletes and their achievements becomes greater and more tangible to me. If Michael Jordan eats them -and I like (and want to be like) Michael Jordan- then I must eat them too. "Fans primarily showed loyalty beyond reason to teams but also relayed their commitment and emotion to athletes, identifying with those brands, and being inspired by those brands" (Ruihley and Pate 2017). The influence of the celebrity endorser on sports fans is clear to the extent that today's athletes are also expected to have moral obligations to act a certain way because of the influence they have on fans (Archer and Matheson 2019). In a sense, sports fans develop deep relationships with athletes that often mimic real-life social interactions. Attention to today's social activist athletes illustrates this point. Celebrity athletes who use their notoriety to spread social movements, such as the Black Lives Matter movement in America, take on a role much greater than simply the athlete playing a game in the field. Responsible citizenship, meritocracy, and interdependence in the effort to increase social consciousness play critical roles in how fans interpret and react to athlete activists (Kaufman and Wolff 2010). Star athletes involved in social activism might also be deliberate in their actions regarding their activism, thus playing a part in the development and maintenance of the star's celebrity brand (Coombs and Cassilo 2017). Unsurprisingly, fans with especially high levels of fandom will interpret and react to these parasocial relationships much more often and with more intensity than less-identified fans (Earnheardt and Haridakis 2009).

The effect of star athletes' behavior on fans' identities; their level of fandom; longevity of fandom; and propensity to gather with other fans; is often profound. Modern athletes affect not only what happens in the sports world, but beyond as well. Football players kneeling during the national anthem, for example, illustrates players' power to influence beyond the sport. It makes sense, therefore, that if one's self-identity is so intertwined to an outside influence such as a team or athlete, then it is only natural for fans to want to associate and connect to teams and players who demonstrate qualities admiral to those fans. However, that is not to say that fans' attraction to athletes cannot be changed.

Athlete scandal is nothing new, but today's speed of communication and the types of imagery available via social media often makes them more impactful on fans than in years past. Video and images of star athletes engaged in domestic violence, drug use, and racists acts shows fans a side of their favorite athletes that might have been either impossible to see before or more easily suppressed by teams and attorneys in the past. Cellphone technology where people record for themselves these types of actions, or security camera footage, leave many fans with little means to defend their favorite athletes and their attachments to them. 
From a commercial standpoint, fans favorably judge brands that cut ties with athletes involved in scandals and negativity (Sato et al. 2020). This shows the impact of athlete actions on fans' perceptions and the appropriateness of maintaining their fan relationship with them. In addition, whether or not an athlete purposefully engaged in the negative behavior also affects fans' attitudes toward them. An athlete who actively and intentionally behaves badly will have a more difficult time mending their relationships with fans than athletes whose actions are perceived to be unintentional. More involved fans, or "diehard" fans, however, are less likely to see accidental misbehavior as a major reason to cut ties with athletes than less-involved fans (Sato et al. 2015). Lee et al. (2016) found "...highly identified fans seem to regulate negative emotions but deliberately select moral disengagement reasoning strategies to maintain their positive stance toward the wrongdoer... (p. 176). Essentially "diehard" fans judge negative athlete actions less harshly than lesser fans whose attachment and engagement with them is less significant and important than it is for more impassioned fans. Moral rationalization is easier for "diehard" fans than with less-engaged fans when it comes to interpreting athletes' negative behaviors. Moral decoupling on the other hand, enables even lesser fans to judge athletes' indiscretions with less criticism because it enables them to admire positive on-field performance in the face of negative offfield actions (Lee et al. 2015). That is not to say that admiration equates to forgiveness. Image repair strategies that actively address past transgressions enable fans to forgive athletes more easily (Lee and Kwak 2017). While performancecenteredness allows some athletes to maintain their positive public image while others cannot, (i.e., the better the athlete in terms of skill, the more likely they are to restore their image) it is a combination of off-field reparations with on-field performance that enables fans to positively judge athletes involved in scandal. Traditionally, it is performance, however, that has and continues to most influence fans' connected identities to their favorite teams and players.

\section{BIRGing and CORFing}

Cialdini et al.'s BIRGing and CORFing Theory (1976) explains why winning teams attract more fans than losing teams. According to this theory, teams like the New England Patriots would appeal to people more than the Washington Football Team, simply based on the teams' unprecedented performance over the past decade. Cialdini et al.'s BIRG (Basking in Reflected Glory) refers to fans' tendency to "...share the glory of a successful other with whom they are in some way associated" (p. 366). For instance, BIRGing explains fans' inclination to wear team merchandise after a win to publicize their connection to the team, allowing them to vicariously share in the team's success. Based on the BIRG tendency, Green Bay Packers fans, for example, are more likely to wear team merchandise on Monday morning following a Sunday win than after a loss. University of Oregon professor Madrigal (1995) confirms this, stating, "The behavior manifestation of an increased association may take the form of wearing clothing that features the team's logo or extolling the virtues of the team to others" (p. 206). 
Cialdini agrees, saying BIRGing occurs when fans publicize their connection for the team through clothes, painting face, etc., even though the fans have not really contributed to the team's success. Snyder (1986) adds that human nature makes people want to associate with success and those who are successful. In contrast, the tendency for fans to CORF (Cut off Reflected Failure) explains why some sports fans disassociate themselves from losing teams. In other words, the Green Bay Packers jersey might be more easily left in the closet on a Monday after a bad team loss. Hirt (1992) adds that CORFing is an image protection tactic that allows fans to distance themselves from a losing team and its lack of success. But does that theory apply to highly evolved, strongly self-identified fans too?

Wann and Branscombe (1991) did not agree with this generalized application of the CORFing tendency for all fans. For them, "diehard" fans believe that being a fan is such an important part of who they are, that they will persevere even when their team loses - in essence, being a fan of a losing team is a badge of honor for the "diehard fan". For lesser fans, CORFing might be a defense mechanism used to protect themselves from their teams' failures. Some might categorize such fans as "fair-weather fans". Additional research confirms this tendency. Madrigal (1995) found that fans with a high identification with their team are more likely to BIRG while those with less identification are more likely to CORF. In essence, the level of fandom plays an integral role in the continued maintenance of fans' selfidentity. The more vested fans are in their team, the more likely they are to remain connected to it during losing seasons or following especially bad losses. At this point in the development of the sports fan, the growth of the fan is predicated not only on the performance of the team or athlete, but also on the intensity or level of fandom. The distinction between the "diehard" and "fair-weather" fan becomes clearer at this point.

Cialdini studied fans of amateur sports to develop his BIRG and CORF models; University of Missouri-Rolla psychology professor End (1991) applied the BIRGing and CORFing theories to professional sports. End studied National Football League fans who used the internet to reinforce their identity with their team when it won; in other words, they BIRGed. End found that fans, especially in the post-season, will use the internet to BIRG or gloat, which boosts their own feelings of joy and adequacy while allowing them to denigrate fans of unsuccessful teams. The ardent Green Bay Packers fan will take to social media and commentary sections to openly express their love of their team. Fans now publicly illustrate their commitment and connection to their favorite team and athlete. At this point, fans' self-identities are so powerfully associated with the teams and players they support, the next logical step is to find other like-minded individuals to share and show-off their newfound identity with. Moreover, the fan community, which arises from individuals' development of sports-fan self-identities, hold sociological implications that can be found in any group. Everyone is not created equal in fan communities, nor are their roles within it. Like any group, there are leaders and followers. Katz and Heere (2013) found in their study of college football game tailgating events that "A newly formed community is not a homogenous or random network of individuals but rather a network where a select few persons have many more connections, and thus a heightened importance..." (p. 283). A 
later study found that these select individuals in the fan group are so important that sports team management must find ways to engage lesser fans due to the untapped revenues available from these large groups of non-"diehard" fans (Katz and Heere 2015). Accordingly, fan groups are hierarchical with certain fans taking on more important and more respected roles within the fan community. These communities and their social structures arise from self-identities, as well as the identities others within the group place on certain individuals.

One can see the progression of the novice fan deliberating on the team, player, or sport to follow in the early stages of fandom; how much importance to place on them as their fandom grows; and ultimately how to reinforce their identities by teaming up with others like them. This enables fans to not only reinforce their connections to teams and players, but also establish themselves as the bigger or the biggest fan among their peers. Additionally, it creates bonds that enable fans to develop camaraderie and a shared group mentality or groupthink that allows them to reinforce their commitments to the team, as well as fend-off fans of rival teams. This phenomenon can be seen in cities that include out-of-town sports bars. For example, Kansas City Chiefs fans can congregate and commune together even in New York City's Brooklyn Borough. Major cities often include these types of establishments where fans of out-of-town teams can meet, eat, and drink while their favorite teams, whose home stadiums might be thousands of miles away, play of multiple television screens.

\section{The Communal Experience}

The 1939 Olympics was the first live televised sporting event, and since that time, television has become sports fans' number-one means of following teams and athletes, and in turn, provides them a communal interface in which to interact with fellow fans. Fans gather around televisions to watch, root for, and sometimes commiserate with each other. Studies suggest that the need for televised sports centers on fans' self-identified personalities and their need for stimulation (Little and Zuckerman 1986). Watching televised sporting events can take on the same role as watching a major motion picture with its drama, characters, and even its violence. Zillman (1989) found that televised sports viewers levels of arousal depend on what is happening in the game and how it is being presented. For some, televised games' levels of violence enable fans to vicariously live out aggressions they would otherwise be unable to do (Wann et al. 1999). Sometimes, the competition even moves from the field to the living room. The shared experience of watching sporting contests with fellow fans enables them to understand and contextualize the events on the field through the lenses of their individual everyday understanding of how things work. These individual understandings are then combined through the shared experience, thus enabling the development of a new, group experience (Holt 1995). In his two-year observational study of baseball fans in Chicago's Wrigley Field bleachers, Holt (1995) found:

Spectators use interpretative frameworks to experience professional baseball in three different ways: through accounting, spectators make sense of baseball; through 
evaluating, spectators construct value judgements regarding baseball; and through appreciating, spectators respond emotionally to baseball (p. 3).

The shared experiences of sports spectatorship include many facets of community, and in a way, microcosms of society in general where there are established roles, rules, and expectations of group members. In addition, the role and level of fandom within the community influences even the experience of watching sports together.

Fans with higher levels of identification with a team actually experience the game and interpret and remember it differently than lesser fans, even though both segments of the fan community are watching the same game. More highly identified fans, or "diehard" fans tend to recall boring and exciting game wins with equal fervor, while lesser fans felt the same about boring game wins and exciting losses (Jang et al. 2018). The distinction between the two fan groups illustrates the deeply ingrained experience of sports as interpreted by fans with differing roles and expectations within the communal fan experience.

Based on these roles, the communal experience of viewing sporting contests together can enable fans to even establish their dominance over one another as well - the idea of outdoing a "lesser" fan by knowing more about trivial facts, how long they have been a fan, etc. can be more easily demonstrated in the communal experience than by one's self. "Diehard" Green Bay Packers fans can impress lesser fans by displaying their knowledge of obscure facts about the team while they are all gathered around to watch a game. The joys of showing off one's level of fandom experienced by highly self-identified fans can be profound.

McDaniel et al. (2007) argue that watching sports can stimulate viewers while also maintaining that arousal for long periods of time. "...for millions of people the excitement of watching their teams compete is the greatest thrill they have except for sex" (Zuckerman 1994, p. 156). The shared emotional ups and downs are more dramatically felt with others than alone. The Green Bay Packers fan feels the emotions of fandom more easily and powerfully with other, like-minded fans. These emotional fluctuations can by as much a physical sensation as they are psychological. Some studies (Hillman et al. 2004, Bernhardt et al. 1998) suggest that physiological responses to games directly correlate with fans' level of engagement and identification with teams and players, affecting heartrates and testosterone levels during key times of games. Others (Kreft 2012) contend it is sports' inherent dramatism that affects fans - its aesthetics and challenges - which influences fans' physical and emotional responses. Because these responses can be so powerful, not to mention so eagerly anticipated, highly self-identified fans look for ways to prolong the experience as much as possible. Just as today's means to view games from thousands of miles away enables fans to never miss out on a contest, so too does it affect the communal experience of sports fandom. For instance, Voci (2006) found that soccer fans self-categorized themselves differently if they viewed games in person as opposed to those who viewed them remotely, thus illustrating the impact of actual in-person gameday experiences on fans and the effect of depersonalizing the communal fan experience.

Gantz et al. (2012) found that sports fans prepare for games and events through rituals and emotional exercises to psyche themselves up long before games. This 
helps explain why fans will meet together in parking lots hours before a game to tailgate with one another. These fan-generated events extend the shared experience of sports fandom. Studies suggest that sports fans are unique in their desire to be together with one another while at these kinds of events. Wenner (1989) concluded that sports fans differed from non-sports fans because of their inherent emotional connection to the communal nature of watching sports together. Watching sports is the ultimate communal experience for highly developed fans. Fans who watch sports together develop a social interaction and community that enables greater, and quicker, relationship building than non-sports fans. Generally, sports fans participate in group activities and interact with one another more often than their non-fan counterparts (Gantz et al. 1995). Gantz et al. (2006) found, "[Fans] begin early, thinking about an upcoming game, searching for information about it on the Web and in print, talking about it with their friends, and planning their schedules so as not to miss any of the action" (p. 114). Sports fans engage in such behavior and activities to share the pleasure of watching sports (Gantz et al. 2006). Knobloch-Westerwick et al. (2009) specified these pleasures, finding that highly developed fans' levels of suspense and engagement with each another came from their rooting for one team over another. In other words, fan levels of anxiety, excitement, and nervousness were directly related to the level of support they have for their team - "diehard" Green Bay Packers fans experience these passions much more fervently than passive Packers fans. David et al. (2008) explained that these highly developed fans' levels of satisfaction, or entertainment value during a sporting event is of course dependent on the events of the game, but can even more so be affected by the very ritual of watching sports together.

This might help explain the high levels of passion exhibited by sports fans following momentous occasions such as winning, or even losing, a championship or other important games. Serazio (2008) argues that these celebrations can become "quasi-religious" experience where those involved become inextricably linked to one another, even for just a moment. Great numbers of people come together, such as during championship parades, or take to the streets following a game, for the communal experience, which Rowe (2003) states is similar to tribal rituals where sports become reflexive for society and the opportunity for mass communication. As one example, tens of thousands of Philadelphia Eagles fans spilled out onto the streets of that city following their Super Bowl victory in 2018, and more than 200,000 fans attended the team's championship parade later that week. The commitment to attend such events illustrates the importance of the inperson communal experience. But, with today's communication technologies, the group experience is no longer limited to just physical connections between fans. New and social media technology enables "virtual" communal connections where fans from all of the world can experience the highs and lows of fandom together. Additionally, fans distanced from the geographical fan community, for example a Manchester United fan living in Japan, experiences the fan relationship differently than with those living nearer to the team's home, in this case Manchester. These remote fans also develop relationships in more unique ways than with those who experience their fandom closer to the team's home. 
Distanced fans are expected to engage with the team and their fellow fans in the same ways that fans who live closer to the team act (Behrens and Uhrich 2020). Essentially, a Manchester fan living in Japan should dress, behave, and manage their fandom with the team in a similar fashion as a fan living in Manchester. The expectation of the community is that fans, even those living in the other side of the world, should express their connections to their teams the same as those living near the team. Displaced fans, or those who moved from their team's geographical location, also illustrate the impact of fan level on fandom.

Collins et al. (2016) study of football fans who moved from their team's residences found that higher-level fans, or "diehard" fans, continued to show the greatest fervor for their team compared to lesser fans still residing in the team's city. A "diehard" Manchester fan who moves to New York, for example, will therefore display a greater level of fandom than a lesser fan still living in Manchester. The separation of fan levels regarding the consumption of online content about the team also plays a role in distanced-fan relationships and behaviors. In a study of Chinese basketball fans, Pu and James (2017) found that distanced fans who simply watch games online do not develop strong relationships with teams, whereas highly connected, or "diehard" fans, were most likely to spend the most amount of time searching, viewing, and participating with fan activities via online and social media.

\section{The Impact of Social Media}

Sports fans' communication via social media continues to see tremendous growth (Pegorao 2014). Social media interaction among sports fans is second nature, and fans' use these platforms for specific reasons. Kang (2017) found that sports fans focused their mobile content on information, service, and interaction. Linked with mobile technology, online and social media have changed the communication styles of sports fans. "A mobile device allows fans to become actively involved with content related to professional sports" (Kang 2017, p. 454). Online communication allows fan groups to collectively band together as well (McCarthy et al. 2014). Fans are no longer suppressed from interacting with each other by time or distance. Moreover, the spread and ease of use of online communication allows fans to strengthen their collective influence while simultaneously reinforcing their self-identities (McCarthy 2012). Sandvoss (2005) found that online, collective fan groups can be best described as extreme involvement activities for fans. The process helps fans make meaning of their relationship to the sport and to themselves. The accessibility of online communication to immediately connect to fellow, highly developed fans provides an outlet for their social needs, which was previously unavailable (Kietzmann et al. 2011). For example, Green Bay Packers fans stationed in Iraq can virtually share the game-time experience with fellow fans in Wisconsin. Today's most popular platforms like Twitter motivate sports fans to make their opinions widely known, even though the limitations of the platform also can constrain their communication at the same time (Witkemper et al. 2012). 
Use of newer social media platforms like Snap Chat by newer generations of fans shows that they still seek to commune with fellow their fans, even if it is through means different than their predecessors (Haug et al. 2015). Here, one can see the evolution of the communal sports experience keeping pace with the evolution of communication technology. Platforms such as Snap Chat, which are more ephemeral in nature than Twitter or Facebook, enable sports fans to communicate their points of view with each other in the moment (Billings at al. 2017). In other words, a particular play in a football game might seem of the utmost importance at the time someone posts a comment about it, but it might also be as quickly forgotten as the game progresses. Billings et al. (2017) study found that Snap Chat, while not perfect in its design, is the current platform of choice for sports fans. That study also found that Snap Chat sports fan users feel that posting comments is as important as the actual game occurring in the moment. Interestingly, many sports fans do not use Snap Chat to engage in two-way communication with sports figures, which is more doable today than ever before. Rather, they are motivated to communicate collectively, which further illustrates the importance that highly developed sports fans place on communing and communicating with each other in large groups. They are not motivated by the social media platform's ability to engage in individual, two-way communication. Instead, sports fans are more interested in speaking to and listening to large groups of similarly minded sports fans - thus the virtual communal sports fan experience. Spinda and Puckette (2018) found that Snap Chat usage to follow sports was based on four motives: ease and convenience; behind the scenes; vicarious experience; and unique points of view. The use of social media as a group communication tool is a necessity to the modern sports fan (Ballouli and Hutchinson 2010).

The inextricable place that social media have on online communal fan experiences exists because fans place so much importance on sharing their thoughts about athlete and team achievements - in some ways, "proving" their fandom (Pieper 2013). In any situation where groups of followers so fervently connect themselves to a sports team, the natural human inclination is to celebrate one's self and denigrate those who hold opposing views. The criticism of social media as a place for bullying and negativity holds true for the sports fan as well. The communal sports fan experience can move from like-minded individuals sharing their love of a team or athlete with one another to that of a group banding together to criticize and ridicule the opposition. Online sports rivalries are born. Athletes simply want to win for personal and financial reward, but followers of those them crave victory because it means they are emotionally and spiritually better than their rivals, even though fans might not have technically contributed to the on-the-field victory of "us over them". Fans' self-identification with their teams and the act of communing with others like them can be so great that rivalries can turn fans of a team into truly fanatical groups pitting themselves against anyone and everyone who thinks differently than them - a unified front of us against them. 


\section{Nationalism and "Us against Them"}

Just as social identity theory can help explain how individuals develop deep bonds and associations with sports teams and athletes, self-categorization theory helps to explain the "us versus them" mentality, or dichotomy found in communal sports fandom. Demographic and psychographic variables, and combinations of these elements, often dictate the behaviors and thoughts of sports fans gathered in groups (Turner et al. 1987). In addition, self-categorization theory also helps to explain how nationalism affects sports fandom since highly emotional sporting events can often pit groups against each other. This is seen most evidently during major nationalistic sporting events because of how clearly defined in and outgroup membership is during these contests (McPherson 1976).

In their examination of the 2016 Olympic Games, Billings et al. (2019) found that social identity among highly self-identified fans was comprised of patriotism, smugness, and internationalism, and that these qualities are so ingrained in fans that they might not even know it. Rose et al. (2020) posited that these types of viewpoints are in fact ingrained - that it frames fans' views about their country and its athletes, as well as themselves. A similar study of the 2018 Winter Olympics found that fandom level was the determining factor affecting fans' degree of patriotism and support for their own country (Brown et al. 2020). Nineteen years earlier, Bairner (2001) found “...sports and nationalism are arguably two of the most emotive issues in the modern world" (p. xi). Much of this nationalistic sporting social identity rests on fans' views of themselves and their world. These viewpoints have evolved over time as technology and media coverage has similarly evolved. Mutz and Gerke's (2018) study of the German national Olympic team showed emotional involvement in a team can be affected by how it is framed; finding that nationalism for the German team was less in the 1970s when the media covered it with less emotional fanfare than today's focus on national symbols and patriotic music. The influence of pervasive and often biased media coverage from traditional, as well as user-generated social media, on communal sports fan experiences influences and shapes their world views. Groups of fans can be whipped into a frenzy, and groupthink can overcome individual judgement and decision-making processes. "...the extent to which a fan feels a psychological connection to a team and the team's performance are viewed as selfrelevant" (Wann 2006, p. 332). The competitive nature of sports can spill over to the nature of fandom.

Sports fandom, by its very nature, pits people against each other, just as the teams on the field compete against one another. Wann and Dolan (1994b) found that an in-group's perceptions about an out-group strengthen the bond of the ingroup - essentially the bonds of one team's fans can be strengthened through their collective dislike of another. Even today for Americans, animosity exists most fervently during United States Olympic contests played against the Russian team compared with other nations, even though the Cold War ended decades ago. Longstanding rivalries coupled with highly developed fans create the perfect conditions for the "us versus them" mentality. 
Bernache-Assollant et al. (2007) found in their study of soccer fans that the BIRG phenomenon was strongest for the most highly developed fans. The tendency to blast or ridicule competing fans was similarly not found in lesser fans. The group-fan experience of pitting one against the other grows strongest during periods of elation, especially with rival teams - in other words, the joyous emotions of winning over a hated rival can often stronger than the sorrow of losing (Greenspan 2003). Essentially, because team performance poses a vital threat to fans, the tendency to gloat over a team's victory is stronger than the desire to criticize when it loses. This confirms Cialdini's (1976) finding that fans of winning teams will show the team logos and attire and speak of themselves with the group pronouns "we" or "us" more often after victories than when the team loses. In all, commiseration among sports fans is not as strong as celebration. Subgroups of fans of the same team may also self-identify differently according to team performance, and therefore treat members of the same in-group differently.

Self-described "diehard" fans might not get along as well with those whom they deem as lower-class or "fair weather" fans, even though they are both cheering for the same team (Wann and Branscombe 1990). Gantz et al. (1995) affirm that sports team fandom is directly linked to fans' outward displays of emotion based on team performance, and that the degree of fandom is also on team performance - "diehard" fans will always be fans of the team regardless of its performance whereas "fair-weather" fans will be fans only when the team is successful. In other words, a "diehard" fan, one who has been supportive and loyal through the good and bad times, might see lesser fans, or "fair-weather" fans, as inferior and develop animosity toward them. Essentially, "diehard" fans might think, "Where were you [fair-weather fan] when the team was in last place, when I (diehard fan) still went to games and watched and supported them?" These feelings illustrate the divide that can exist between "diehard" fans and "fairweather" fans. These less-developed fans might also be "urged" to become fans in areas where support for a certain team is especially high and the cultural norm for citizens of a particular city. On the other hand, in areas where a team's support is relatively low, the "fair-weather" fan phenomenon is less likely to occur. In other words, if there is little wide-spread involvement in team fandom in a particular city, that team's large-scale fanbase is likely to comprised of more developed or "diehard" fans (Asada et al. 2020).

Regardless of the level of fandom, the desire to show outward expression rests heavily on the need for fans to reinforce "their" success when their team wins. Again, this might be seen as an irrational reaction given the fact that it is the athletes on the field, not the fans, who ultimately determine team success. Nonetheless, as with most large groups of people collected together for one, highly emotional reason, the communal sports fan experience is ripe for the highest of the highs and the lowest of the lows. Fans of opposing teams will often feel intimidated or uneasy about wearing team merchandise in an area where their team is the feuding adversary, especially if they are alone (Chang et al. 2019). The communal sports phenomena enable groups of opposing fans to unite and form a kind of pack while in the territory of their rivals. From this highly charged atmosphere comes the development of a group dynamic or communal identity 
created from the collection of many comparably developed individual selfidentities - the group identity.

\section{From Self-Identity to Group-Identity}

The creation of the group identity rests in the ability of its members to first develop strong individual self-identities; reinforce and build on those selfidentities; share those identities with others like them; and ultimately for the group to think and behave as one. Self-identity can best be described as the way people think about themselves based on their membership in a group (Turner and Reynolds 2010). The individual in combination with the group is at the heart of all social processes (Turner et al. 1987). As noted in the Social Identity Theory and Sports Fans section, individual social identity plays an integral part on the development of sports fan groups. As individuals' social identities take on greater importance to them and their lives, it equally affects their associations with others, namely similarly self-identified fans. This explains the progression from selfidentity to group-identity, or the communal fan identity. For example, the progression helps explain why fans of Manchester City are different than fans of Manchester United, despite the fact that they are fans of the same city's football clubs. Heere et al.'s (2011) study of fans of three Florida university sports teams found that fans most strongly identified with the teams than the state, and that the relationships between fans and teams are unique in this sense. These groups identify themselves very differently from each other because of the evolution of their members' self-identities. That is, even though both groups of fans are very close to one other geographically, they may be very far apart in terms of how they think and act as fans of their respective teams, even if they are both in the same city. Sports fans want to share their views and opposing perspectives, but also reaffirm shared ideals with others who feel the same as they do (Ragas and Kiousis 2008).

Accordingly, fans of the same sport, in the same city, desire to commune and associate with others like them and dissociate with the opposition even if it is comprised of neighbors, co-workers, and even relatives who might live next door. Social identity, like identifying as a fan of a particular team or sport, is linked to peoples' connection to those teams and players (Turner 1982). These connections dictate the roles of fans, how they see themselves in their roles, and how they behave and interact with their fellow fan group members (Fink et al. 2009). For example, people tend to gravitate to these groups comprised of people most like themselves, which again helps explain why fans will pour into the streets to celebrate or commiserate with their fellow fans and why a Green Bay sports bar might exist in Chicago. Fan group members' identifications are also evident in their engagement with both the team and fellow fans during the heights of fan exuberance or the depths of despair. Their identification with the team is important during the competition on the field, but their identification with the fan group takes on a separate role following these times of extreme happiness and sadness after the competition on the field is over. Sanderson et al.'s (2016) analysis of group 
identities found that the prominent themes among group members included: (a) renouncing fandom; (b) punishment commentary; (c) racial commentary; (d) general criticism; (e) attacking other group members; and (f) presenting the 'facts' of the case (p. 309). Moreover, they discovered that these themes were evident in social media communication, as well face-to-face interactions, with $75 \%$ of Facebook conversations and $100 \%$ on Twitter focused on these six themes for sports fans. Sanderson et al. (2016) focused their study on social activism and its effects on fans. They found that social media provide the means for fan groups to disagree, but also reinforce their bonds while challenging societal norms in the face of changing public opinion.

The general negativity of these themes confirms Branscombe et al. (1999) findings that a value threat, such as a criticism against a team or player, acts as a threat to the entire fan group. Consequently, the overall feel of the group experience for sports fans tends to lean toward denigrating the opposition more than boosting the favored team or athlete. The group identity for most sports fans rests on their reliance to band together to fend off the opposition through negativity. Once again, and not surprisingly, this negativity seems to have increased as social media use increased, especially among Twitter users, which seems to be the most vitriol of social media platforms (Browning and Sanderson 2012, Ferrara et al. 2016). The evolution of sports fan groupthink appears to move into a type of safety in numbers mentality - it is much easier to criticize or even insult others when there is a group of other like-minded individuals to supply backup. This type of involvement on a communal level tends to affect those members with the greatest vested interest in the team. Essentially, those whose personal identities are so thoroughly intertwined with the team they support experience games differently than those within the group who feel as though they have less hanging in the balance on a win or loss. The stronger the fandom level, the stronger the need to be involved with the team. "Diehard" fans require the most maintenance in their sports team relationships.

\section{Sports Team Identification and "Diehard Fans"}

Funk and James (2001) recognized that team fandom is directly affected by fan involvement with the team, known as Sport Team Identification (STI). Keaton et al. (2014) furthered this idea finding that the psychological effects of sports fandom are more connected with STI than purely emotional responses, which might include variables such as family, team characteristics, and athletic performance. This means that the identifications and relationships developed through sports fandom run deeper than the individual superficial variables associated with fandom. In other words, the overall fan experience is more important than on-field results, scores, family traditions of rooting for a specific team, etc. Rather, it is the culmination of these variables that make sports fans who they are - essentially, the sum of fandom is greater than its parts. Furthermore, these effects are much greater in fans who self-identify their allegiance to a team as central to their overall identity compared to less-identified fans. Devlin and 
Brown's (2017) study of 715 sports fans found that personality traits are directly related to team identity, which in turn, affects the amount of involvement fans need and who they need it from. The unique traits or characteristics of a team and city can therefore greatly affect fans' identities. That is, a Los Angeles Rams fan will differ in their personality traits than a Green Bay Packers fan because of the difference between the teams, but also because of difference in their home cities. These traits include honesty/humility; emotionality; extraversion; agreeableness; and openness to experiences. Without these traits, "fair-weather" fans will not likely ever evolve into "diehard" fans.

The reasons individuals choose to consume sports coverage, which directly influences their self-identity as casual or "diehard" fans, comes from the dispositions of the individuals and their emotional responses to games; the content or drama of the game; as well as the fulfillment one receives by being around other similarly minded fans (Raney 2013). The evolution from the individual, non-fan to the "diehard" fan can be seen as a transformation of the individual in terms of identity, psychology, and interactivity with others, which helps to reinforce and cement the eventual transformation into the "diehard" fan. Figure 1 illustrates the differences in the developmental decision-making processes of the "diehard" fan versus the casual fan.

\section{Discussion and Conclusion}

Based on the preceding insight literature review, it can be concluded that the development of the sports fan from an individual to the "diehard" fan begins with their desire to take-on the traits and characteristics of the team and athletes most important to them. Sports fans seek out ways to develop themselves into something they feel can boost their sense of self-worth and, in later stages, a sense of belonging to a group of similarly minded individuals. The last step of this process for fervent sports fans is to distinguish themselves as fans who are most knowledgeable, most sincere, and most loyal during the teams' ups and downs the "diehard fan". Sharing their sense of accomplishment during the developing stages of sports fandom with other fans through communal experience is of immense importance to them. Fans at this level gather with others who share a similarly strong sense of devotion. Even lesser fans can be sought for as companionship because it provides "diehard fans" the opportunity to show off their superior levels of fanaticism to those whom they believe to be inferior. The mentality of "I've been a fan for x number of years, through the good and bad; I know all the statistics; I've been to x number of games, etc." enables the fullest most highly self-identified fan to revel in and reinforce their highly evolved sense of self-identity. Fans' personalities change and new self-identifications are made during the fan development process showing others through communal experiences the passion and pride they now possess, which they did not have prior to realizing their fullest fan potential. 
Figure 1. Decision Tree of the "Diehard Fans" and Casual Fans

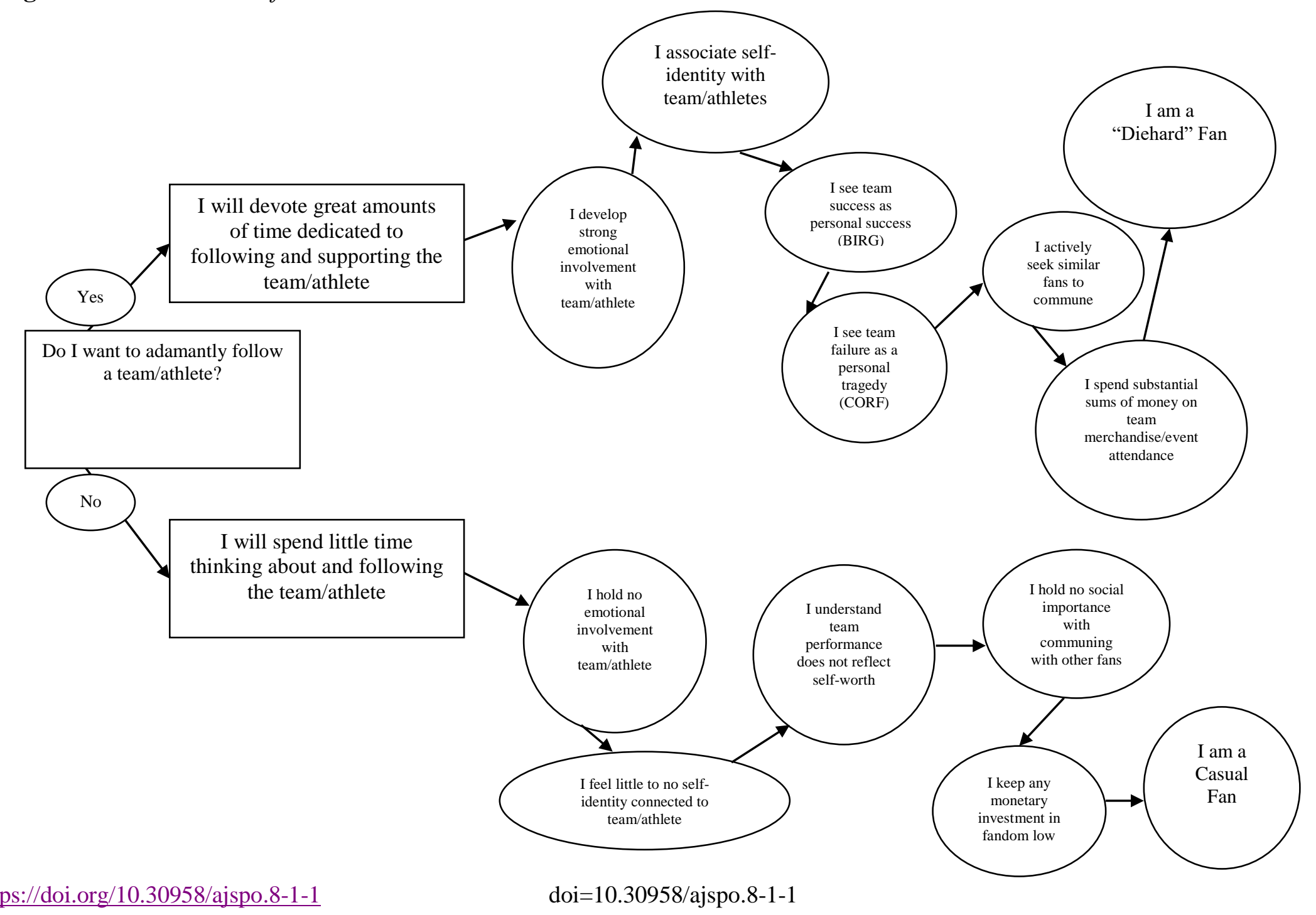


Figure 2. The Stages of Fan Self-Development and Self-Identification of "Diehard Fan"

An individual becomes interested in a team or athlete. Interest can arise from outside influences such as family, friends, etc., or from an individual desireto be part of the fan experience and develop or reinforce one's self to the team, its player, location, history, etc.

\section{The individual begins adpating his or her self-identity to match that of the team or athlete (Tajfel, 1990).}

A team's "brand" or image becomes intertwined with that of the fan. Fans at this stage outwardly show their connection to their team by wearing team merchandise, attending team-related events, and using pronouns such "we" and "us" when describing the team. Increased levels of self-identification with the team are apparent at this fans do not yet have a highly-developed sense of identity that is inextricably linked with the team yet.

Changes occurs where the indivdual takes on the "personality" of the team or athlete as if it is his or her own (Burke, 1991; Borgatta, 1992). The team "brand" referenced in stage two becomes a true part of the

individual's self-identity. The team the fan follows becomes as important as who the fan is, or was before the process began. This is where New Castle fans, for example, take on the role of supporter of the team, as well as pseudo-ambassador of the city, and defender of it.

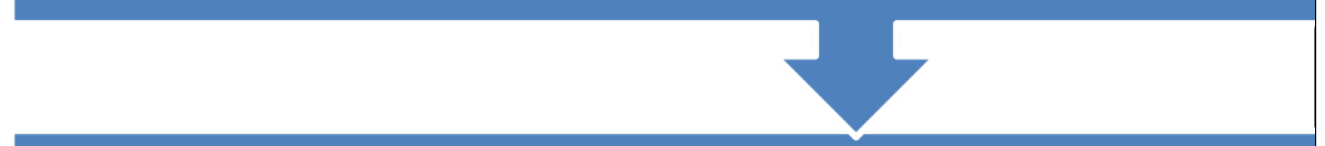

The individual looks to athletes as role models to mimic and replicate and/or to claim thier

acccomplishments as his or her own (Lavarie, 2000; Hogg, 1995). The team and its players are no longer

simply sports teams and athletes playing a game. Rather, they take on mythic and heroic status for the

ever-developing, self-idenitfied sports fan. Athlete spokespersons develop their greatest power of persusion over more

highly self-identified fans at this point.

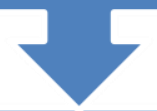

The individual wants to openly express his or her attachment to teams and athletes to the outside with greater regularity and with more emphasis becuase of the psychological effects (joy) of showing team support to the outside world. This is evident in the BIRG tendency (Cialdini, 1976; Wann \& Dolan, 1994; End, 1991). Reflecting the glory of team victory in powerful, outward ways reflects the glory of victory for the fan. Both triumphs are inextricably intertwined with each another for the ever-growing, more significantly developed self-identitified sports fan.

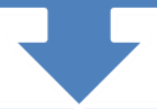

The individual feels elation when the team wins and interprets that success as a feeling of belonging. Losses can result in a temporary cutting-off of ties to the team. This is seen in the CORF tendency (Cialdini, 1976; Hirt, 1992). Less-identified fans can easily cut-off reflected failure of the team whereas the highly self-identified fan remains ever loyal, supportive, and optimistic of future success. The divide between fans with lower levels of self-identification with the team and those whose identities are completely linked with the team become evident at this point.

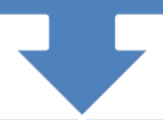

The individual seeks out other like-minded individuals to commune with and share in the devotion to the team and/or athlete - the communal experience (Snow \& Oliver, 1995; Wenner, 1989; Sezario, 2008). Tailgating hours before a game in freezing weather; devoting disproportinate sums on event attendance; resecheduling major life events for team-related activities are all examples of the highly self-identified fan's lifestyle at this point. Fellow fans take-on critically important roles in these family-like relationships that are developed during this stage.

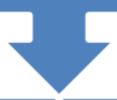

The most highly-progressed and most-deeply self-identified fan can be described as the "diehard" fan following the development of the sports fan during the preceding steps (Thoits \& Virshup, 1997; Diamanche, 1994; Strvker, 1968). For some, this process might take little time, whereas others mis reach this level of ultimate self-fulfillment and complete self-identification for some time. The duration of this process will, undoubtedly, depend on the individual. However, the process is indicative of the developmental stages that sports fans undergo if they reach the level of "diehard" fan. All fans, of course, neither aspire to nor wish that their self-identities be so influenced by sports teams and athletes. 
The development of sports fans is centered on psychological changes from within, which ultimately manifest themselves as outward societal behaviors and actions that continuously reinforce fans' self-identification. These outward expressions are a communal experience. Continued experiences, reinforced selfidentities, and sustained gratifications are achieved by developing into the truest and most sincere sports fan - the "diehard" fan. Figure 2 provides a culminating summary of the processes of "diehard" sports fan development.

\section{Suggestions for Future Research}

The study of sports fandom and self-identity spans decades. In that time, research revealed the importance of sports teams and athletes on the fan psyche. The relationship between sports figures, teams, and even the cities where they compete, play an integral role on fans' sense of self and their relationships with one another. However, changes and advances in technology, public opinion, and societal issues continuously affect sports fandom. Accordingly, future research might focus on the youngest generations of sports fans. At 77 million, Millennials make up not only a substantial portion of the population (1/2 times larger than their predecessor Generation $\mathrm{X}$ ), but are uniquely described as “...creative, solution-focused, socially conscious, and team-oriented" (Devaney 2015, p. 1).

They are the first generation wholly raised with the internet; the first mass users and consumers of social media; and the first to grow up with cellphones as constant companions. This generation is profoundly different from earlier ones in their communication styles and information gathering savvy. Accordingly, they communicate differently, consume information differently, and think about their world differently. More future research on sports fandom should focus on how and why Millennials relate to their favorite teams and athletes compared to previous generations. While research has been done on social media and sports fandom, the fact is that social media platform usage changes so frequently and is replaced by this generation so quickly (Instagram use by Millennials now surpasses Facebook, for example). In addition, research centered on Generation Y might contribute even more revealing information on sports fandom as the generation matures. Therefore, research into the ways Millennials and Generation Y use technology to follow teams and athletes; how they relate to their fellow Millennial/Generation Y fans; and even if sports fandom is as important to them as it was for earlier generations might provide a revealing look into the future of sports fandom and its impact on social-identity, the communal experience, and whether "diehard fans" will even exist in the future.

The COVID-19 pandemic affected every part of life for nearly everyone all over the world. Its effects on sports and sport fandom are profound. Sports seasons were either put on hold or cancelled completely. Even in late 2020, sports stadiums remain empty as teams play to recorded crowd noise. Tailgating is banned. Future research into the pandemic's effects on the sports world might show how the complete loss of competitive sports for several months affected fans. Questions of how quarantine restrictions touched the psychological, 
sociological, and emotional lives of sports fans during this time might reveal new and fascinating insights into the importance of sports fandom on millions of people who were suddenly and unexpectedly without a major part of their lives.

\section{References}

Arai A, Ko YJ, Kaplanidou K (2013) Athlete brand image: scale development and model test. European Sport Management Quarterly 13(4): 383-403.

Arai A, Ko YJ, Ross S (2014) Branding athletes: exploration and conceptualization of athlete brand image. Sport Management Review 17(2): 97-106.

Archer A, Matheson B (2019) Shame and the sports fan. Journal of the Philosophy of Sport 46(2): 208-223.

Asada A, Ko YJ, Jang WE (2020) Effects of relative size and homogeneity of sports fan community on potential fans' support intentions. Journal of Sport Management 34(2): $103-119$.

Bairner A (2001) Sport, nationalization, and globalization: European and North American perspectives. SUNY Press.

Ballouli K, Hutchinson M (2010) Digital branding and social media strategies for professional athletes, sports teams, and leagues: an interview with Digital Royalty's Amy Martin. International Journal of Sport Communication 3(4): 395-401.

Basil M (2012) Admiration: an important determinant of celebrity effectiveness? In American Marketing Winter Educators Conference.

Behrens A, Uhrich S (2020) Uniting a sport teams' global fan community: prototypical behavior of satellite fans enhances local fans' attitudes and perceptions of groupness. European Sport Management Quarterly 20(5): 598-617.

Bernache-Assollant I, Lacassagne M-F, Braddock JH (2007) Basking in reflected glory and blasting: differences in identity-management strategies between two groups of highly identified soccer fans. Journal of Language and Social Psychology 26(4): 381-388.

Bernhardt PC, Dabbs JM, Fielden JA, Lutter CD (1998) Testosterone changes during vicarious experiences of winning and losing among fans at sporting events. Physiological Behavior 65(1): 59-62.

Billings AC, Qiao F, Conlin L, Nie T (2017) Permanently desiring the temporary? Snapchat, social media, and the shifting motivations of sports fans. Communication \& Sport 5(1): 10-26.

Billings AC, Scott OK, Brown KA, Lewis M, Devlin MB (2019) The patriotism down under: nationalized qualities and Australian media consumption of the 2016 Rio Olympic Games. International Review for the Sociology of Sport 54(3): 325-347.

Borgatta E, Borgotta M (1992) Encyclopedia of sociology. MacMillan.

Branscombe NR, Wann DL, Noel JG, Coleman J (1993) In-group or out-group extremity: importance of the threatened social identity. Personality \& Social Psychology Bulletin 19(4): 381-388.

Branscombe NR, Ellemers N, Spears R, Doosje B (1999) The context and content of social identity threat. In N Ellemers, R Spears, B Doosje (eds.), Social Identity: Context, Commitment, Content, 35-58. Blackwell.

Brewer B (1979) In-group bias in the minimal group situation: a cognitive-motivational analysis. Psychological Review 86(30): 307-324. 
Brown KA, Billings AC, Devlin M, Brown-Devlin N (2020) Rings of fandom: overlapping motivations of sport, Olympic, team and home nation fans in the 2018 Winter Olympic Games. Journal of Broadcasting \& Electronic Media 64(1): 20-40.

Browning B, Sanderson J (2012) The positives and negatives of Twitter: exploring how student-athletes use Twitter and respond to critical tweets. International Journal of Sport Communication 5(4): 503-521.

Burke P (1991) Identity processes and social stress. American Sociological Review 56(6): 836-849.

Callero P (1985) Role-identity salience. Social Psychology Quarterly 48(3): 203-215.

Cialdini RB, Borden RJ, Thorne A, Walker MR, Freeman S, Sloan LR (1976) Basking in reflective glory: three (football) field studies. Journal of Personality and Social Psychology 34(3): 366-375.

Chang MJ, Connaughton DP, Ilyoung J, Jihye K, Kang J (2019) The impact of selfcontinuity on fans' pride and word-of-mouth recommendations: the moderating effects of team performance and social responsibility associations. Sport Marketing Quarterly 28(1): 20-33.

Collins DR, Heere B, Shapiro S, Ridinger L, Wear H (2016) The displaced fan: the importance of new media and community identification for maintaining team identity with your hometown team. European Sport Management Quarterly 16(5): 655-674.

Coombs DS, Cassilo D (2017) Athletes and/or activists: LeBron James and Black lives matter. Journal of Sport and Social Issues 41(5): 425-444.

Crawford G (2004) Consuming sport: fans, sport and culture. International Journal of Sports Marketing \& Sponsorship 6(2): 124-139.

David P, Horton B, German T (2008) Dynamics of affect and entertainment in a super bowl audience: a multilevel approach. Communication Research 35(3): 398-420.

Devaney SA (2015) Understanding the millennial generation. Journal of Financial Service Professionals 69(6): 11-14.

Devlin M, Brown N (2017) Using personality and team identity to predict sports media consumption. International Journal of Sport Communication 10(3): 371-392.

Dimanche F (1994) Leisure as symbolic consumption: a conceptualization and prospectus for future research. Leisure Sciences 16(2): 45-53.

Earnheardt AC, Haridakis PM (2009) An examination of fan-athlete interaction: fandom, parasocial interaction, and identification. Ohio Communication Journal 47(1): 27-53.

End C (1991) An examination of NFL fans' computer mediated BIRGing. Journal of Sports Behavior 24(2): 162-181.

Erdogan B (1999) Celebrity endorsement: a literature review. Journal of Marketing Management 15(4): 291-314.

Ferrara E, Varol O, Davis C, Menczer F, Flammini (2016) A The rise of social bots. Communications of the ACM 59(7): 96-104.

Fink JS, Parker H, Martin B, Higgins J (2009) Off-field behavior of athletes and team identification: using social identity theory and balance theory to explain fan reactions. Journal of Sport Management 23(2): 142-155.

Funk DC, James J (2001) The psychological continuum model: a conceptual framework for understanding an individual's psychological connection to sport. Sport Management Review 4(2): 119-150.

Gantz W, Wenner LA, Carrico C, Knorr M (1995) Televised sports and marital relationships. Sociology of Sport Journal 12(3): 306-323.

Gantz W, Want Z, Paul B, Potter RF (2006) Media sports versus all comers: comparing TV sports fans with fans of other programming genres. Journal of Broadcasting \& Electronic Media 50(1): 95-118. 
Gantz W, Fingerhut D, Nadoff G (2012) The social dimensions of sports fanship. In AC Earnhardt, PM Haridakis, BS Hugenberg (eds.), Sport Fans, Identity, and Socialization. Lexington Books.

Greenspan P (2003) A case of mixed feelings: ambivalence and the logic of emotion. In S Leighton (ed.), Philosophy and the Emotions, A Reader, 91-116. Broadview Press.

Giulianotti R, Robertson R (2004) The globalization of football: a study in the glocalization of the "serious life." British Journal of Sociology 55(4): 545-568.

Haug S, Castro RP, Kwon M, Filler A, Kowatsch T, Schaub MP (2015) Smartphone use and smartphone addiction among young people in Switzerland. Journal of Behavioral Addictions 4(4): 299-307.

Hedlund DP (2014) Creating value through membership and participation in sport fan consumption communities. European Sport Management Quarterly 14(1): 50-71.

Heere B, Walker M, Yoshida M, Ko YJ, Jordan JS, James JD (2011) Brand community development through associated communities: grounding community measurement within social identity theory. Journal of Marketing Theory and Practice 19(4): 407422.

Hillman CH, Cuthbert BN, Bradley MW, Lang PW (2004) Motivated engagement to appetitive and aversive fanship cues: psychophysical responses of rival sports fans. Journal of Sport \& Exercise Psychology 26(2): 333-351.

Hirt E (1992).The costs and benefits of allegiance: changes in fans self-ascribed competencies after team victory versus team defeat. Journal of Personality and Social Psychology 63(5): 724-738.

Hogg MA, Terry DJ, White KM (1995) A tale of two theories: a critical comparison of identity theory with social identity theory. Social Psychology Quarterly 58(4): 255269.

Holt DB (1995) How consumers consume: a typology of consumption practices. Journal of Consumer Research 22(1): 1-16.

James J (2001) The role of cognitive development and socialization in the initial development of team loyalty. Leisure Sciences 23(4): 233-261.

Jang W, Wann D, Ko Y (2018) Influence of team identification, game outcome, and game process on sport consumers' happiness. Sport Management Review 21(1): 63-71.

Jenkins R (2008) Social identity. $3^{\text {rd }}$ Edition. Taylor \& Francis.

Kang S (2017) Mobile communication and pro sports: motivation and fan loyalty. International Journal of Mobile Communications 15(6): 604.

Katz M, Heere B (2013) Leaders and followers: an exploration of the notion of scale-free networks within a new brand community. Journal of Sport Management 27(4): 271287.

Katz M, Heere B (2015) Empowerment within brand communities: overcoming the Achilles' heel of scale-free networks. Sport Management Review 18(3): 370-383.

Katz M, Ward RM, Heere B (2018) Explaining attendance through the brand community triad: integrating network theory and team identification. Sport Management Review 21(2): 176-188.

Kaufman P, Wolff EA (2010) Playing and protesting: sport as a vehicle for social change. Journal of Sport and Social Issues 34(2): 154-175.

Keaton SA, Gearhart CC, Honeycutt JM (2014) Fandom and psychological enhancement: effects of sport team identification and imagined interaction on self-esteem and management of social behaviors. Imagination, Cognition and Personality 33(3): 251-269.

Kenyon GS, McPherson BD (1974) An approach to the study of sport socialization. International Review for the Sociology of Sport 9(1): 127-139. 
Kietzmann H, Hermkens K, McCarthy IP, Silvestre BS (2011) Social media? Get serious! Understanding the functional building blocks of social media. Business Horizons 54(3): 241-251.

Knobloch-Westerwick S, Prabu D, Eastin MS, Tamborini R, Greenwood D (2009) Sports spectators' suspense: affect and uncertainty in sports entertainment. Journal of Communication 59(4): 750-767.

Kolbe RH, James JD (2000) An identification and examination of influences that shape the creation of a professional team fan. Inter-national Journal of Sports Marketing and Sponsorship 2(1): 14-28.

Kreft L (2012) Sport as a drama. Journal of the Philosophy of Sport 39(2): 219-234.

Lee JS, Kwak DH (2017) Can winning take care of everything? A longitudinal assessment of post-transgression actions on repairing trust in an athlete endorser. Sport Management Review 20(3): 261-272.

Lee JS, Kwak DH, Moore D (2015) Athletes' transgressions and sponsor evaluations: a focus on consumers' moral reasoning strategies. Journal of Sport Management 29(6): 672-687.

Lee JS, Kwak DH, Braunstein-Minkove JR (2016) Coping with athlete endorsers' immoral behavior: roles of athlete identification and moral emotions on moral reasoning strategies. Journal of Sport Management 30(2): 176-191.

Levarie D (2000) Factors affecting fan attendance: the influence of identity salience and satisfaction. Journal of Leisure Research 32(2): 227-299.

Little, P., \& Zuckerman, M. (1986). Sensation seeking and music preferences. Personality and Individual Differences, 7(4), 575-577.

Lock DJ, Funk DC (2016) The multiple in-group identity framework. Sport Management Review 19(2): 85-96.

Lock D, Heere B (2017) Identity crisis: a theoretical analysis of 'team identification' research. European Sport Management Quarterly 17(4): 413-435.

Madrigal R (1995) Cognitive and affective determinates of fan satisfaction with sporting event attendance. Journal of Leisure Research 27(3): 205-227.

McCall G, Simmons J (1996) Identities and Interactions. Free Press.

McCarthy B (2012) A sports journalism of their own: an investigation into the motivations, behaviours, and media attitudes of fan sports bloggers. Communication \& Sport 2(1): 65-79.

McCarthy J, Rowley J, Ashworth C, Pioch E (2014) Managing brand presence through social media: the case of UK football clubs. Internet Research 24(2): 181-204.

McDaniel S, Choonghoon L, Mahan III J (2007) The role of gender and personality traits in response to ads using violent images to promote consumption of sports entertainment. Journal of Business Research 60(6): 606-612.

McPherson BD (1976) Socialization into the role of sport consumer: a theory and causal model. Canadian Review of Sociology 13(2): 165-177.

Melnick MJ, Wann DL (2004) Sport fandom influences, interests, and behaviors among Norwegian university students. International Sports Journal 8(1): 1-13.

Melnick MJ, Wann DL (2011) An examination of sport fandom in Australia: socialization, team identification, and fan behavior. International Review for the Sociology of Sport 46(4): 456-470.

Mutz M, Gerke M (2018) Major sporting events and national identification: the moderating effect of emotional involvement and the role of the media. Communication \& Sport 6(5): 605-626.

Parry KD, Jones I, Wann DL (2014) An examination of sport fandom in the United Kingdom: a comparative analysis of fan behaviors, socialization processes, and team identification. Journal of Sport Behavior 37(3): 251-267. 
Pegoraro A (2014) Twitter as disruptive innovation in sport communication. Communication and Sport 2(2): 132-137.

Petkus E (1996) The creative identity: Creative behavior from the symbolic interactionist perspective. Journal of Creative Behavior 30(3): 189-196.

Pieper LP (2013) It's a whole new ball-game: how social media is changing sports. Journal of Sport Management 27(3): 261-262.

$\mathrm{Pu}$ H, James J (2017) The distant fan segment: exploring motives and psychological connection of International National Basketball Association fans. International Journal of Sports Marketing and Sponsorship 18(4): 418-438.

Ragas MW, Kiousis S (2008) Intermedia agenda-setting and political activism: Moveon. org and the 2008 presidential election. Mass Communication \& Society 13(5): 560583.

Raney AA (2013) Reflection on communication and sport on enjoyment and disposition. Communication \& Sport 1(1-2): 164-175.

Reifurth KRN, Bernthal MJ, Heere B (2018) Children's game-day experiences and effects of community groups. Sport, Business and Management: An International Journal 8(3): 257-275.

Rose M, Rose GM, Merchant A, Orth UR (2020) Sports teams heritage: Measurement and application in sponsorship. Journal of Business Research 124(1):759-769.

Rowe D (2003) Sport and the repudiation of the global. International Review for the Sociology of Sport 38(3): 281-294.

Roy S, Mishra S (2018) The dual entertainment theory in celebrity endorsements. Journal of Advertising Research 58(1): 33-50.

Rubin A (2009) Uses-and-gratifications perspective on media effects. In J Bryan, MB Oliver (eds.), Media Effects: Advances in Theory and Research, 165-185. Routledge.

Ruihley B, Pate J (2017) For the love of sport: examining sport emotion through a lovemarks lens. Communication \& Sport 5(2): 135-159.

Sanderson J, Frederick E, Stocz M (2016) When athlete activism clashes with group values: social identity threat management via social media. Mass Communication and Society 19(3): 301-322.

Sandvoss C (2005) Fans. Polity Press.

Sato S, Ko YJ, Park C, Tao W (2015) Athlete reputational crisis and consumer evaluation. European Sport Management Quarterly 15(4): 434-453.

Sato S, Arai A, Tsuji Y, Kay M (2020) When should a brand cut ties with a scandalized endorser? Communication \& Sport 8(2): 215-235.

Serazio M (2008) Virtual sports consumption, authentic brotherhood. Hugenberg.

Smith JA (2019) Destabilization, adaptation and the long-term fan object: the search for continuity in later-life sports fandom. Journal of Fandom Studies 7(2): 169-188.

Snow D, Oliver P (1995) Social movements and collective behavior: social psychology dimensions and considerations. In K Cook, G Fine, J House (eds.), Sociological Perspectives on Social Psychology, 571-600. University of Chicago Press.

Snyder C (1986) Distancing after group success and failure: basking in reflected glory and cutting off reflected failure. Journal of Personality and Social Psychology 51(2): 382-388.

Spaaij R, Anderson A (2010) Psychosocial influences on children's identification with sports teams: a case study of Australian Rules football supporters. Journal of Sociology 46(3): 299-315.

Spinda JSW, Puckette S (2018) Just a snap: fan uses and gratifications for following sports Snapchat. Communication \& Sport, 6(5): 627-649. 
Stryker S (1968) Identity salience and role performance: the relevance of symbolic interaction theory for family research. Journal of Marriage and the Family 30(4): $558-564$.

Tajfel H (1970) Experiments in intergroup discrimination. Scientific American 23(5): 96102.

Tajfel H, Turner JC (1986) Social identity theory of intergroup behavior. In W Austin, S Worchel (eds.), Psychology of Intergroup Relations, 33-47. $2^{\text {nd }}$ Edition. Nelson-Hall.

Theodorakis ND, Wann DL (2008) An examination of sport fandom in Greece: influences, interests, and behaviours. International Journal of Sport Management and Marketing 4(4): 356-374.

Thoits P, Virshup L (1997) Me's and we's: forms and functions of social identities. In R Ashmore, L Jussim (eds.), Self and Identity: Fundamental Issues, 206-133. Oxford University Press.

Turner JC (1982) Towards a cognitive redefinition of the social group. In H Tajfel (ed.), Self, Identity, and Intergroup Relations, 15-40. Cambridge University Press.

Turner JC, Reynolds KJ (2010) The story of social identity. In T Postmes, N Branscombe (eds.), Rediscovering Social Identity: Core Sources. Psychology Press.

Turner JC, Hogg MA, Oakes PJ, Reicher SD, Wetherell MS (1987) Rediscovering the social group: a self-categorization theory. Basil Blackwell.

Van Driel II, Gantz W, Lewis N (2019) Unpacking what it means to be - or not be-A fan. Communication \& Sport 7(5): 611-629.

Voci A (2006) Relevance of social categories, depersonalization and group processes: Two field tests of self-categorization theory. European Journal of Social Psychology 36(1): 73-90.

Vorderer P (2000) Interactive entertainment and beyond. In D Zillman, P Vorderer (eds.), Media Entertainment: The Psychology of its Appeal, 21-36. Lawrence Erlbaum Associates.

Wang J, Braunstein-Minkove JR, Baker TA, Li B, Zhang JJ (2020) Self-branding through NFL team fanship: fans' desired self-image and its implications for branding practices. Sport Marketing Quarterly 29(1): 47-61.

Wann D (1994) Biased evaluation of highly identified sports spectators: a response to Hirt and Ryalls. Perceptual and Motor Skills 79(1994): 105-106.

Wann DL (2006) The causes and consequences of sport team identification. In A Raney, J Bryant (eds.), Handbook of Sport and Media, 331-352. LEA.

Wann DL, Branscombe NR (1990) Die-hard and fair-weather fans: effects of identification on BIRGing and CORFing tendencies. Journal of Sport \& Social Issues 14(2): 103117.

Wann D, Dolan T (1994a) Influence of spectators' identification and evaluation of the past, present and future performance of a sports team. Perceptual and Motor Skills 78(2): 547-552.

Wann DL, Dolan TJ (1994b) Attributions of highly identified sport spectators. The Journal of Social Psychology 134(6): 783-792.

Wann DL, Carlson JD, Holland LC, Jacob BE, Owens DA, Dayne-Wells D (1999) Beliefs in symbolic catharsis: the importance of involvement with aggressive sports. Social Behavior and Personality: An International Journal 27(2): 155-164.

Wann DL, Melnick MJ, Russell GW, Pease DG (2001) Sports fans: the psychology and social impact of spectators. Routledge.

Wenner LA (1989) Media, sports, and society. SAGE Publications.

Witkemper C, Lim CH, Waldburger A (2012) Social media and sports marketing: examining the motivations and constraints of Twitter users. Sport Marketing Quarterly 21(3): 170-183. 
Yoshida M, Heere B, Gordon B (2015) Predicting behavioral loyalty through community: Why other fans are more important than our own intentions, our satisfaction, and the team itself. Journal of Sport Management 29(3): 318-333.

Zillman D (1989) Enjoyment from sports spectatorship. Goldstein.

Zuckerman M (1994) Behavioral expressions and biosocial bases of sensation seeking. Cambridge University Press.

\section{Appendix A. Search Strategies}

Articles sourced from the following four databases focused on social and psychological relevance to sports fandom development as it relates to how and why an individual becomes initially interested in fandom and progresses to a strong, die-hard level. Articles relating to branding, marketing, political attitudes, gender, and non-sports fandom, such as pop music, were excluded. Articles published before 1968 were excluded.

\begin{tabular}{|l|c|c|c|}
\hline Database & Keywords & Results & Articles \\
\hline JSTOR & Fandom AND Identity & 2,722 & 1,390 \\
\cline { 2 - 4 } & Fandom AND Sport & 932 & 410 \\
\cline { 2 - 4 } & Sports Fan AND Development & 15,091 & 5,789 \\
\cline { 2 - 4 } & Sports Fan AND Identification & 4,551 & 2,300 \\
\cline { 2 - 4 } & $\begin{array}{c}\text { Sports Fan AND } \\
\text { Motivation }\end{array}$ & 3,453 & 1,462 \\
\cline { 2 - 4 } & $\begin{array}{c}\text { Sports Fan AND } \\
\text { Relationships }\end{array}$ & 8,178 & 3,166 \\
\cline { 2 - 4 } & $\begin{array}{c}\text { Sports Fan AND } \\
\text { Communal }\end{array}$ & 2,890 & 931 \\
\cline { 2 - 4 } & Fan Socialization & 2 & 2 \\
\cline { 2 - 4 } & Fan Community & 169 & 169 \\
\cline { 2 - 4 } & Sport Socialization & 49 & 4 \\
\cline { 2 - 4 } & Athlete Brand & 38,091 & 15,290 \\
\hline
\end{tabular}

\begin{tabular}{|l|c|c|c|}
\hline & Keywords & Results & Articles \\
\hline ProQuest & Fandom AND Identity & 2,343 & 1,598 \\
\cline { 2 - 4 } & Fandom AND Sport & 2,062 & 831 \\
\cline { 2 - 4 } & $\begin{array}{c}\text { Sports Fan AND } \\
\text { Development }\end{array}$ & 32,663 & 9,550 \\
\cline { 2 - 4 } & $\begin{array}{c}\text { Sports Fan AND } \\
\text { Identification }\end{array}$ & 5,996 & 3,960 \\
\cline { 2 - 4 } & $\begin{array}{c}\text { Sports Fan AND } \\
\text { Motivation }\end{array}$ & 7,427 & 3,617 \\
\cline { 2 - 4 } & $\begin{array}{c}\text { Sports Fan AND } \\
\text { Relationships }\end{array}$ & 29,643 & 9,391 \\
\cline { 2 - 4 } & $\begin{array}{c}\text { Sports Fan AND } \\
\text { Communal }\end{array}$ & 1,969 & 1,021 \\
\cline { 2 - 4 } & Fan Socialization & 3,592 & 3,088 \\
\cline { 2 - 4 } & Fan Community & 159,138 & 42,945 \\
\hline
\end{tabular}




\begin{tabular}{|c|c|c|}
\hline Sport Socialization & 11,562 & 10,118 \\
\hline Athlete Brand & 23,485 & 3,693 \\
\hline Total & 277,537 & 78,664 \\
\hline
\end{tabular}

\begin{tabular}{|l|c|c|c|}
\hline Database & Keywords & Results & Articles \\
\hline $\begin{array}{l}\text { Communication } \\
\text { Source }\end{array}$ & Fandom AND Identity & 99 & 86 \\
\hline \multirow{1}{*}{} & Fandom AND Sport & 74 & 61 \\
\cline { 2 - 4 } & $\begin{array}{c}\text { Sports Fan AND } \\
\text { Development }\end{array}$ & 66 & 40 \\
\cline { 2 - 4 } & $\begin{array}{c}\text { Sports Fan AND } \\
\text { Identification }\end{array}$ & 55 & 41 \\
\cline { 2 - 4 } & $\begin{array}{c}\text { Sports Fan AND } \\
\text { Motivation }\end{array}$ & 27 & 19 \\
\cline { 2 - 4 } & $\begin{array}{c}\text { Sports Fan AND } \\
\text { Relationships }\end{array}$ & 110 & 85 \\
\cline { 2 - 4 } & $\begin{array}{c}\text { Sports Fan AND } \\
\text { Communal }\end{array}$ & 2 & 2 \\
\cline { 2 - 4 } & Fan Socialization & 942 & 1,416 \\
\cline { 2 - 4 } & Fan Community & 7,416 & 1,076 \\
\cline { 2 - 4 } & Sport Socialization & 1,846 & \\
\cline { 2 - 4 } & Athlete Brand & 11,548 & \\
\cline { 2 - 4 } & Total & & 1,528 \\
\cline { 2 - 4 }
\end{tabular}

\begin{tabular}{|l|c|c|c|}
\hline Database & Keywords & Results & Articles \\
\hline $\begin{array}{l}\text { Academic } \\
\text { Search Ultimate }\end{array}$ & Fandom AND Identity & 212 & 205 \\
\cline { 2 - 4 } & Fandom AND Sport & 374 & 294 \\
\cline { 2 - 4 } & $\begin{array}{c}\text { Sports Fan AND } \\
\text { Development }\end{array}$ & 705 & 282 \\
\cline { 2 - 4 } & $\begin{array}{c}\text { Sports Fan AND } \\
\text { Identification }\end{array}$ & 316 & 276 \\
\cline { 2 - 4 } & $\begin{array}{c}\text { Sports Fan AND } \\
\text { Motivation }\end{array}$ & 152 & 104 \\
\cline { 2 - 4 } & $\begin{array}{c}\text { Sports Fan AND } \\
\text { Relationships }\end{array}$ & 846 & 423 \\
\cline { 2 - 4 } & $\begin{array}{c}\text { Sports Fan AND } \\
\text { Communal }\end{array}$ & 16 & 90,736 \\
\cline { 2 - 4 } & Fan Socialization & 3,736 & 13,818 \\
\cline { 2 - 4 } & Fan Community & 80,562 & 13,818 \\
\cline { 2 - 4 } & Sport Socialization & 4,149 & 103,768 \\
\cline { 2 - 4 } & Athlete Brand & & \\
\cline { 2 - 4 } & Total & & 3,181 \\
\cline { 2 - 4 }
\end{tabular}




\section{Appendix B. Inclusion and Exclusion Criteria}

Study Characteristics

\begin{tabular}{|c|c|c|c|}
\hline & Description & Inclusion & Exclusion \\
\hline $\begin{array}{l}\text { Study } \\
\text { Focus }\end{array}$ & $\begin{array}{l}\text { Studies focused on the } \\
\text { psychological and } \\
\text { sociological factors } \\
\text { affecting sports fan } \\
\text { development }\end{array}$ & $\begin{array}{l}\text { Empirical studies that } \\
\text { describe the } \\
\text { relationship between } \\
\text { identity, self, } \\
\text { community, and sports } \\
\text { fandom }\end{array}$ & $\begin{array}{l}\text { Empirical studies that } \\
\text { describe the } \\
\text { relationship between } \\
\text { identity, self, } \\
\text { community, and non- } \\
\text { sports fandom }\end{array}$ \\
\hline Outcomes & $\begin{array}{l}\text { Study results centered } \\
\text { on variables relating to } \\
\text { sports fans' thoughts, } \\
\text { behaviors, and actions }\end{array}$ & $\begin{array}{l}\text { Outcomes relating to } \\
\text { fandom, identity, } \\
\text { development, } \\
\text { identification, } \\
\text { motivation, } \\
\text { relationships, and } \\
\text { communal experiences }\end{array}$ & $\begin{array}{l}\text { General fan activities } \\
\text { not relating to the } \\
\text { psychological and } \\
\text { communicative } \\
\text { essence of sports } \\
\text { fandom }\end{array}$ \\
\hline $\begin{array}{l}\text { Study } \\
\text { Method }\end{array}$ & Empirical & $\begin{array}{l}\text { Qualitative and } \\
\text { quantitative } \\
\text { methodologies }\end{array}$ & $\begin{array}{l}\text { Experimental } \\
\text { methodologies }\end{array}$ \\
\hline \multirow[t]{2}{*}{ Data } & Observable & $\begin{array}{l}\text { Sports fans' natural } \\
\text { actions and behaviors } \\
\text { reflective of their } \\
\text { thoughts }\end{array}$ & $\begin{array}{l}\text { Manipulated variables } \\
\text { affecting behaviors }\end{array}$ \\
\hline & Communication & $\begin{array}{l}\text { Written and spoken } \\
\text { language }\end{array}$ & $\begin{array}{l}\text { Language resulting } \\
\text { from artificially } \\
\text { produced variables }\end{array}$ \\
\hline
\end{tabular}

Study Characteristics

\begin{tabular}{|l|c|c|}
\hline Year of Publication & Studies from 1968 & Studies prior to 1968 \\
\hline Publication Language & Articles written in English & $\begin{array}{c}\text { Articles not written in } \\
\text { English }\end{array}$ \\
\hline Publication Status & $\begin{array}{c}\text { Accepted articles published } \\
\text { in books and peer-reviewed } \\
\text { publications }\end{array}$ & $\begin{array}{c}\text { Self-published works, } \\
\text { encyclopedia entries, and } \\
\text { editorial commentary }\end{array}$ \\
\hline
\end{tabular}


